ORIGINAL ARTICLE

\title{
Non-invasive ventilation as a first-line treatment for acute respiratory failure: "real life" experience in the emergency department
}

\author{
C Antro, F Merico, R Urbino, V Gai
}

Emerg Med J 2005;22:772-777. doi: 10.1136/emj.2004.018309

See end of article for authors' affiliations

.....................

Correspondence to: Camillo Antro, Dipartimento di Emergenza e Accettazione, Ospedale San Giovanni Battista, 10126 Torino, Corso Bramante 88/90, Italy; c.antro@tiscalinet.it

Accepted for publication 7 November 2004 with non-invasive ventilation (NIV) for patients with acute Objective: To describe our experience with non-invasive
respiratory failure (ARF) in the emergency department (ED). Methods: A prospective/retrospective, observational study on 190 patients with ARF (mean \pm SD age $72.2 \pm 12.9$ years, mean APACHE II score 18.9 \pm 5.9 ), who received $200 \mathrm{NIV}$ trials in an ED. We analysed the NIV register data (prospectively collected) and medical records (retrospective data abstraction) and evaluated clinical indications for NIV, patient outcomes, and predictive factors for success and death. NIV success was defined as tolerance of the procedure and no need for endotracheal intubation (ETI).

Results: Main indications to NIV were cardiogenic pulmonary oedema (CPE) (70 trials), acute exacerbation of COPD (39), both CPE and acute exacerbation of COPD (11), pneumonia (48), decompensation of obesity/hypoventilation (6), other conditions (26). The procedure was successful in $60.5 \%$ of trials. Global mortality was $34.5 \%$, similar to the APACHE II predicted mortality of $32 \%$. ETI rates were $6.5 \%$ and tracheostomy rates $1 \%$. The improvement of $\mathrm{pH}$ within six hours after NIV initiation was predictive of survival in the hypercapnic group.

Conclusions: Our results confirm the global efficacy of NIV in an ED setting, and show that, in spite of lower success rate in "real practice" in comparison with RCTs, an intermediate care unit can represent an appropriate and less expensive setting to perform this technique. The low rate of ETI seems to be because of the high number of patients for whom NIV was used as "ceiling" treatment.
$\mathrm{N}$ on-invasive ventilation (NIV) consists of mechanical breaths delivered by a tightly fitting nasal or facial mask or a helmet instead of an artificial airway, such as an endotracheal or tracheostomy tube. A number of prospective randomised controlled trials (RCTs) $)^{1-7}$ and meta analyses $^{8-10}$ has demonstrated that NIV is effective and safe for selected patients with acute respiratory failure (ARF). When ARF is because of acute exacerbations of chronic obstructive pulmonary disease (COPD), NIV is now considered standard of treatment. ${ }^{11}{ }^{12}$ In patients with hypoxemic cardiogenic pulmonary oedema (CPE) resistant to standard medical treatment, continuous positive airway pressure (CPAP) (which is here considered a mode of NIV even if it is not assisted ventilation) has been shown to reduce intubation rate and accelerate the recovery. ${ }^{13}{ }^{14}$ Non-invasive pressure support ventilation seems to reduce intubation rate in the subgroup of CPE patients with hypercapnia. ${ }^{15}$ Patients with ARF because of other diseases and conditions have been treated with NIV with some benefit, ${ }^{16-18}$ so extending the indications for this ventilatory technique. However, RCTs show that NIV has beneficial effects in the setting of a research study, which are not automatically reproducible in the real clinical practice, where less selected populations of patients are treated and less intensive care and monitoring can be provided, except for an intensive care unit (ICU). In addition, although in randomised trials reductions of intubation and death rates are considered primary clinical goals, these may not always be considered realistic objectives in everyday clinical practice. Actually, palliation, comfort, and relief of dyspnoea can represent acceptable end points of NIV for patients with poor prognosis or who refuse advanced life support. For these patients, NIV can be utilised as "ceiling" treatment. In this study, we describe the experience of our emergency department (ED) with NIV as first-line treatment in patients with ARF and analyse the outcomes in relation to the clinical goals previously established for each individual patient.

\section{METHODS}

This study was conducted from January 2002 to March 2003 in an ED of a university-affiliated urban hospital with 1200 beds, which includes a 19 bed high dependency unit (HDU). The unit provides acute care and monitoring for critically ill or high risk patients who are admitted from the emergency ward and who do not immediately require or are not otherwise candidates for invasive mechanical ventilation. It provides an acute NIV service, which is also available for inpatients who develop ARF while staying in surgical or medical wards for other reasons. Emergency physicians manage the unit, rotating between it and the emergency ward approximately every three months. The medical HDU staff are divided in two teams, each composed of one full time senior physician, three full time junior doctors, and two residents, each rotating over two 6 hours and one 12 hour shifts. All physicians have been formally trained in the delivery of NIV and in airway management, and a rapid access to endotracheal intubation (ETI) and invasive

Abbreviations: APACHE II, Acute Physiology and Chronic Health Evaluation II score; ARF, acute respiratory failure; CAP, community acquired pneumonia; COPD, chronic obstructive pulmonary disease; $\mathrm{CPAP}$, continuous positive airway pressure; $\mathrm{CPE}$, cardiogenic pulmonary oedema; ECG, electrocardiogram; ED, emergency department; EPAP, expiratory positive airway pressure; ETI, endotracheal intubation; HDU, high dependency unit; ICU, intensive care unit; IPAP, inspiratory positive airway pressure; NIV, non-invasive ventilation; PEEP, positive end expiratory pressure; $\mathrm{RCT}$, randomised controlled trials 
mechanical ventilation is guaranteed without delay 24 hours a day. However, the experience and expertise in NIV administration of medical staff are highly variable. In addition, because of a large shortage of nurses during 2002, nurse:patient ratio was $1: 4$ in the first shift, down to $1: 6$ or 1:9 in afternoon and nocturnal shifts, which sometimes reduces nursing care and monitoring capability to critical levels. No dedicated respiratory therapist was available in the unit during the period of study. Adherence to the practical guidelines of American Thoracic Society ${ }^{19}$ and British Thoracic Society ${ }^{20}$ was generally maintained on NIV administration. Criteria for initiating NIV were the presence of moderate to severe dyspnoea plus either $\mathrm{pCO}_{2}>45 \mathrm{~mm} \mathrm{Hg}$ with $\mathrm{pH}<7.35$ or $\mathrm{PaO}_{2}<60 \mathrm{~mm} \mathrm{Hg}$ with $\mathrm{FiO}_{2}$ up to 0.6. In patients with hypercapnic ARF because of chest wall deformity, neuromuscular disorder, morbid obesity, or decompensated obstructive sleep apnoea, a NIV trial could be started even in absence of respiratory distress, as these patients often present with depressed mental status associated to abnormal gas exchange. The critical pathway of our hospital allows patients presenting to the ED with ARF (or developing it while in hospital wards) to be evaluated by both an ICU specialist and an ED staff member, who together make a decision about the need for invasive or non-invasive ventilatory assistance and where to admit the patient: in ICU or in HDU. Usually, a NIV trial is offered to each patient with ARF who has no need for immediate ETI or who declines it or is not otherwise a candidate for ETI because of poor prognosis of underlying disease or advanced age. Whenever possible, a management plan is made before initiating a NIV trial about what to do in case of a NIV trial failure-that is, either to intubate and mechanically ventilate the patient or to consider the NIV trial as a "ceiling" treatment, taking into account the stage of underlying disease, the patient or family's wishes about advanced life support, and the available beds in ICU. During the study, NIV was provided initially in the emergency room and continued there as long as a HDU bed became available. Because of the limited availability of HDU beds, the length of stay in the emergency room could prolong for many hours.

Most of the time, Ventilators Vision (Respironics, Murrysville, PA, USA) were used, which permitted delivery of known concentrations of oxygen and direct monitoring of pressure, volume, and flow during ventilation. Conventional ICU ventilators (Evita 2, Draeger, Lubeck, Germany or Horus Taema, France) were used when the synchronisation between patient and ventilator was difficult or when the clinician believed the patient to be at high risk of NIV failure. Facial masks were used either exclusively or in the period of stabilisation and adapting to NIV. Some patients who were able to breath with closed mouth could subsequently use nasal masks. The bilevel pressure support was the most commonly used mode of ventilation; CPAP was used for patients with pulmonary oedema without hypercapnia. In hypercapnic patients, NIV protocol consisted in setting inspiratory positive airway pressure (IPAP) and expiratory positive airway pressure (EPAP) at low levels at the beginning of procedure-for example, $8 / 3$ or $10 / 4 \mathrm{~cm} \mathrm{H}_{2} \mathrm{O}-$ and then in increasing pressure support up to obtain a tidal volume of about $7 \mathrm{ml} / \mathrm{kg}$, a respiratory rate less than 25 breaths/min, and patient comfort. EPAP was increased to counterbalance intrinsic positive end expiratory pressure (PEEP) and improve inspiratory triggering. In hypoxemic patients, CPAP was set initially at $5-6 \mathrm{~cm} \mathrm{H}_{2} \mathrm{O}$ and gradually increased up to obtain haemoglobin saturation $>90 \%$ with $\mathrm{FiO}_{2}<60 \%$. Generally, each patient was subjected to monitoring of electrocardiogram (ECG), blood pressure, heart rate, respiratory rate, $\mathrm{SpO}_{2}$, arterial blood gas levels, and clinical status during the first hours of ventilation and subsequently depending on severity of ARF and availability of equipment. Central venous and peripheral artery accesses were also obtained for selected patients who required more intensive monitoring.

Two of us (CA and FM) analysed patients' data, which were in part prospectively collected from the NIV register of the unit (demographic data, baseline physiological variables, arterial blood gas data, NIV mode) and in part retrospectively obtained from the medical records through data abstraction forms (indication to and duration of NIV, pressure and $\mathrm{FiO}_{2}$ settings, outcomes such as need for endotracheal intubation, HDU and hospital mortality, HDU and hospital length of stay). The competent Hospital Authority approved access to patient medical records and use of data. Every effort was made to understand the clinical indications for NIV and the underlying disease(s), based on emergency physician's notes, progressive notes of the HDU physician in charge, and final diagnosis on medical record at discharge. The success of NIV trial was defined as tolerance of the procedure and avoidance of ETI. Failure of a NIV trial was defined as either intolerance of the procedure or need for ETI, which was the presence of any of the following criteria within 14 days of admission: a) $\mathrm{pH}<7.20$; b) $\mathrm{pH} 7.20-7.25$ on two occasions one hour apart; c) hypercapnic coma; d) $\mathrm{PaO}_{2}<45 \mathrm{~mm} \mathrm{Hg}$ despite of maximal tolerated $\mathrm{FiO}_{2}$, and e) cardiorespiratory arrest. ${ }^{5}$ If any of these criteria was met, the patient could be offered ETI or continued medical treatment with or without NIV, depending on patient and family's wishes and the attending physician and ICU specialist's combined evaluation in relation to the goals of treatment.

We also tried to estimate the predictive value of some factors (chosen a priori), which other authors have suggested being associated with NIV success or failure. ${ }^{21} 2217$

\section{STATISTICAL ANALYSIS}

The descriptive analysis was performed for the overall NIV population and for single categories of disease. Results are presented as absolute values and frequencies, means and standard deviations, or medians and interquartile ranges. Predictive factors for response to NIV and for death were identified by univariate analysis: independent variables included Acute Physiology and Chronic Health Evaluation (APACHE) II score, arterial blood gas values (basal pH and $\mathrm{pCO}_{2}$ ), and level of consciousness, adjusted for sex and age. As predictors of death, we have also considered the absence of improvement of $\mathrm{pCO}_{2}$ and of $\mathrm{pH}$ within six hours after NIV initiation. Predictors are expressed as odd ratios (OR) and their 95\% confidence intervals (CI). Variables that were univariately associated with either response to NIV or death $(p<0.2)$ were considered for the final stepwise logistic regression. Analysis was performed using STATA version 8.0 (Stata, College Station, Texas, USA, 2003).

\section{RESULTS}

Altogether, 190 patients (93 women) with a mean $( \pm$ SD) age of $72.2 \pm 12.9$ years and a mean APACHE II score of $18.9 \pm 5.9$ received a NIV trial for 200 episodes of ARF during the study period. Eight patients received two trials and one patient received three trials for distinct episodes of ARF. Baseline characteristics of global population on admission are shown in table 1 .

Main clinical indications to NIV and characteristics of each indication group are reported in table 2 .

The ventilation modes were bilevel pressure support (172 trials) and CPAP (25 trials). Two patients who started with CPAP were shifted to bilevel positive airway pressure ventilation because of unsuccessful CPAP. In one patient, the ventilation mode was not specified. Median pressure settings were IPAP $16 \mathrm{~cm} \mathrm{H}_{2} \mathrm{O}$ (interquartile range 
Table 1 Baseline characteristics of 190 patients with acute respiratory failure (ARF) treated with non-invasive ventilation (NIV)

\begin{tabular}{|c|c|}
\hline Characteristics & Number \pm SD (or \%)* \\
\hline $\begin{array}{l}\text { Mean age } \pm \text { SD (years) } \\
\text { Number (\%) female }\end{array}$ & $\begin{array}{l}72.2 \pm 12.9 \\
93(48.9 \%)\end{array}$ \\
\hline $\begin{array}{l}\text { Clinical parameters on admission: } \\
\text { Mean APACHE II score on admission } \\
\text { ( } n=191 \text { trials) }\end{array}$ & $18.9 \pm 5.9$ \\
\hline $\begin{array}{l}\text { Systolic blood pressure }(\mathrm{mm} \mathrm{Hg}) \text { : } \\
\text { mean } \pm \text { SD }\end{array}$ & $138.1 \pm 32.1$ \\
\hline $\begin{array}{l}\text { Diastolic blood pressure }(\mathrm{mm} \mathrm{Hg}) \text { : } \\
\text { mean } \pm \mathrm{SD}\end{array}$ & $82.1 \pm 17.2$ \\
\hline $\begin{array}{l}\text { Heart rate (bpm): mean } \pm S D \\
\text { Respiratory rate (bpm): mean } \pm \text { SD }\end{array}$ & $\begin{array}{l}103.9 \pm 21.1 \\
33 \pm 9\end{array}$ \\
\hline \multicolumn{2}{|l|}{$\begin{array}{l}\text { Mental status, number (\%) of patients } \\
\text { ( } n=199 \text { trials) }\end{array}$} \\
\hline Alert & $137(68.8 \%)$ \\
\hline $\begin{array}{l}\text { Slightly decreased level of } \\
\text { consciousness }\end{array}$ & $47(23.6 \%)$ \\
\hline $\begin{array}{l}\text { Severely decreased level of } \\
\text { consciousness }\end{array}$ & $15(7.5 \%)$ \\
\hline \multicolumn{2}{|l|}{$\begin{array}{l}\text { Median basal arterial blood gas value } \\
\text { (IQR) } \\
\text { pH }\end{array}$} \\
\hline All patients (180/200 trials) & $7.27(7.20-7.34)$ \\
\hline $\begin{array}{l}\text { Hypercapnic patients } \\
\text { (143/144 trials) }\end{array}$ & $7.26(7.18-7.30)$ \\
\hline $\begin{array}{l}\text { Non-hypercapnic patients (37/37 } \\
\text { trials) }\end{array}$ & $7.39(7.32-7.44)$ \\
\hline \multicolumn{2}{|l|}{$\mathrm{PaCO}_{2} \mathrm{mmHg}$} \\
\hline $\begin{array}{l}\text { Hypercapnic patients } \\
\text { (144/144 trials)) }\end{array}$ & $70(57-78)$ \\
\hline $\begin{array}{l}\text { Non-hypercapnic patients ( } 37 / 37 \\
\text { trials) }\end{array}$ & $37(32.8-41)$ \\
\hline \multicolumn{2}{|l|}{$\mathrm{PaO}_{2} \mathrm{mmHg}$} \\
\hline $\begin{array}{l}\text { All patients }(178 / 200 \text { trials }) \\
\text { Hypercapnic patients } \\
\text { (141/144 trials) }\end{array}$ & $\begin{array}{l}57.4(46-72) \\
57(46-72)\end{array}$ \\
\hline $\begin{array}{l}\text { Non-hypercapnic patients } \\
\text { ( } 37 / 37 \text { trials) }\end{array}$ & $60(48-69.4)$ \\
\hline $\begin{array}{l}\mathrm{PaO}_{2} / \mathrm{FiO}_{2} \\
\text { Non-hypercapnic patients } \\
\text { (17/37 trials) }\end{array}$ & $193(115-223)$ \\
\hline \multicolumn{2}{|l|}{ Patients coming from } \\
\hline Emergency room & $157(78.5 \%)$ \\
\hline Medical ward & $26(13 \%)$ \\
\hline Surgical ward & $17(8.5 \%)$ \\
\hline \multicolumn{2}{|l|}{$\begin{array}{l}\text { Clinical indication to NIV, number } \\
\text { (and \%) of trials }\end{array}$} \\
\hline CPE & $70(35 \%)$ \\
\hline COPD exacerbation & $39(19.5 \%)$ \\
\hline CPE and COPD exacerbation & $11(5.5 \%)$ \\
\hline Pneumonia and COPD exacerbation & $21(10.5 \%)$ \\
\hline Pneumonia & $27(13.5 \%)$ \\
\hline \multicolumn{2}{|c|}{ Obesity/hypoventilation decompensation 6 (3\%) } \\
\hline Otherst & $26(13 \%)$ \\
\hline
\end{tabular}

$S D$, standard deviation; IQR, interquartile range; COPD, chronic obstructive pulmonary disease; CPE, cardiogenic pulmonary oedema. *Unless stated otherwise.

tOthers: pleural effusion (4), amyotrophic lateral sclerosis (2), postoperative pulmonary failure (6), lung cancer (4), pulmonary embolism (4), cardiogenic shock (2), septic shock (2), hemophthisis (1), and multiple myeloma (1).

(IQR) 14-18), EPAP $6 \mathrm{~cm} \mathrm{H} \mathrm{H}_{2} \mathrm{O}$ (IQR 5-6), and CPAP $10 \mathrm{~cm}$ $\mathrm{H}_{2} \mathrm{O}$ (IQR 8-10). Median NIV duration was 24 hours (IQR 672 ) and median $\mathrm{FiO}_{2}$ was 0.4 (IQR 0.34-0.5).

Based on the previous definition of success, 121 NIV trials $(60.5 \%)$ were successful and 113 patients were discharged at home alive. Eight patients were considered to benefit from the technique, but successively died because of their underlying diseases (four because of advanced neoplastic disease, two because of acute myocardial infarction, one because of cerebral stroke, and one died 79 days after the NIV trial for unknown cause). Seventy nine trials (39.5\%) failed, 16 of which for intolerance and 63 for procedure inefficacy. Only two of the intolerant patients underwent invasive mechanical ventilation (one was intubated and the other one was subjected to tracheostomy): both were discharged at home alive, together with the other seven who were not intubated. Seven patients intolerant of procedure were not intubated for varied reasons (two for advanced neoplastic disease, three for advanced age, and two refused advanced life support) and died. Thirteen of 63 patients in whom NIV trial failed for inefficacy were intubated and eight survived, one of whom was tracheostomised. The remaining 50 patients of the failure group were not considered candidate for intubation and only two survived to discharge (fig 1).

Mortality in HDU was $27.4 \%$ and global mortality at hospital discharge was $34.5 \%$, which was slightly higher than the death rate predicted by APACHE II (32\%). Median length of stay in HDU was 6 days (IQR 3-10) and median length of stay in hospital was 15 days (IQR 8-26). Endotracheal intubation rate was $6.5 \%$ and tracheostomy was made in $1 \%$ of NIV trials (table 3).

Nasal bridge ulcer was the main complication of NIV, but we cannot report its rate because of missed data on medical records. However, in one patient only the nasal bridge ulcer was the cause of procedure withdrawal.

Success rates and observed and APACHE II predicted mortalities for each main disease category are reported in table 4.

We found that, of the determinants of success evaluated (APACHE II, mental status, basal $\mathrm{pH}$ and $\mathrm{PaCO}_{2}$, and improvement of $\mathrm{pH}$ and $\mathrm{PaCO}_{2}$ within six hours after NIV initiation), the APACHE II score only was a predictive factor of success and of death, both in the global population of patients and in the hypercapnic group. The improvement of $\mathrm{pH}$ within six hours (OR 0.14, CI 95\% 0.03 to $0.62 ; \mathrm{p}=0.009$ ), but not that of $\mathrm{PaCO}_{2}$ (OR 0.33, CI 95\% 0.97 to 1.13 ; p = 0.07) was predictive of survival in the hypercapnic group. Multivariate analysis for the previous factors showed that only APACHE II was an independent predictive factor for response to NIV both in overall population (OR 0.85, CI 95\% 0.79 to $0.91 ; \mathrm{p}=0.001$ ) and in hypercapnic group (OR 0.80, CI $95 \% 0.72$ to $0.89 ; \mathrm{p}=0.001$ ) (Table 5).

\section{DISCUSSION}

A main finding of our study is the feasibility of NIV in an intermediate care unit within the ED, where patients can receive NIV at an earlier stage and with minor utilisation of resource than in ICU. The overall success rate of NIV in our study $(60.5 \%)$ is quite lower than that reported in RCTs, but compares favourably with that of other similar observational studies. Alsous et $a^{23}$ reported a global success rate of $63 \%$ in their retrospective series of 80 patients with ARF ( $80 \%$ with hypercapnic ARF, APACHE II score of 17.2), who, differently from our patients, were treated exclusively with bilevel positive airway pressure in ICU. Level of monitoring and nurse staffing in their setting, certainly superior to those available for our patients, probably helped obtain better outcomes than ours. In another retrospective study of NIV for patients admitted at mixed intermediate and intensive care units with ARF from various causes, Sinuff et al reported that NIV was stopped secondary to improvement in $48.4 \%$ of their patients. ${ }^{24}$ In a successive study by the same authors, the implementation of a guideline for the use of NIV did not obtain better outcomes of care in terms of ETI and mortality rates. ${ }^{25}$ Girault et al demonstrated the clinical efficacy of NIV applied for different indications in a medical ICU, with an 
Table 2 Baseline characteristics of each non-invasive ventilation (NIV) indication group

\begin{tabular}{|c|c|c|c|c|c|c|c|c|c|c|c|}
\hline & $\begin{array}{l}\text { CPE } \\
\text { total }\end{array}$ & Hypercapnic & $\begin{array}{l}\text { Non- } \\
\text { hypercapnic }\end{array}$ & $\begin{array}{l}\text { Pneumonia } \\
\text { total }\end{array}$ & Hypercapnic & $\begin{array}{l}\text { Non- } \\
\text { hypercapnic }\end{array}$ & COPD & $\begin{array}{l}\text { CPE + } \\
\text { COPD }\end{array}$ & $\begin{array}{l}\text { Pneumonia + } \\
\text { COPD }\end{array}$ & $\begin{array}{l}\text { Hypercapnic } \\
\text { pneumonia } \\
\text { +COPD }\end{array}$ & Ob-hypoven \\
\hline $\begin{array}{l}\text { Number trials } \\
\text { (number } \\
\text { patients) }\end{array}$ & $70 *(69)$ & $45(44)$ & $18(18)$ & $27^{*}(26)$ & $12(12)$ & $11(11)$ & $39(37)$ & 11 & $21^{*}(20)$ & $18(17)$ & $6(6)$ \\
\hline Age† & $76.4 \pm 12.5$ & $77.3 \pm 12$ & $76 \pm 10.7$ & $64.9 \pm 14.9$ & $66 \pm 13.7$ & $62.3 \pm 16.8$ & $71.3 \pm 8.1$ & $83.8 \pm 6.4$ & $74.6 \pm 9.9$ & $73.9 \pm 10.1$ & $58.1 \pm 5.4$ \\
\hline$F / M$ & $44 / 25$ & $30 / 14$ & $10 / 8$ & $10 / 16$ & $4 / 8$ & $5 / 6$ & $15 / 22$ & $7 / 4$ & $7 / 13$ & $6 / 11$ & $3 / 3$ \\
\hline $\begin{array}{l}\text { APACHE II } † \\
\mathrm{pH} \ddagger\end{array}$ & $\begin{array}{l}18.3 \pm 5.8 \\
(66 / 70) \\
7.27\end{array}$ & $\begin{array}{l}18.5 \pm 5 \\
(45 / 45) \\
7.24\end{array}$ & $\begin{array}{l}18.7 \pm 6.9 \\
(16 / 18) \\
7.34\end{array}$ & $\begin{array}{l}18.6 \pm 5.1 \\
(27 / 27) \\
7.37\end{array}$ & $\begin{array}{l}20.8 \pm 4.4 \\
(12 / 12) \\
7.31\end{array}$ & $\begin{array}{l}17.7 \pm 5.4 \\
(11 / 11) \\
7.44\end{array}$ & $\begin{array}{l}19 \pm 5.3 \\
(38 / 39) \\
7.26\end{array}$ & $\begin{array}{l}19.4 \pm 6.5 \\
(11 / 11) \\
7.24\end{array}$ & $\begin{array}{l}20.9 \pm 4.5 \\
(21 / 21) \\
7.29\end{array}$ & $\begin{array}{l}21.1 \pm 4.8 \\
(18 / 18) \\
7.27\end{array}$ & $\begin{array}{l}13.5 \pm 5.8 \\
(6 / 6) \\
7.26\end{array}$ \\
\hline & $\begin{array}{l}7.19-7.31 \\
(63 / 70)\end{array}$ & $\begin{array}{l}7.16-7.29 \\
(45 / 45)\end{array}$ & $\begin{array}{l}7.29-7.41 \\
(18 / 18)\end{array}$ & $\begin{array}{l}7.3-7.42 \\
(23 / 27)\end{array}$ & $\begin{array}{l}7.16-7.36 \\
(12 / 12)\end{array}$ & $\begin{array}{l}7.39-7.47 \\
(11 / 11)\end{array}$ & $\begin{array}{l}7.21-7.3 \\
(38 / 39)\end{array}$ & $\begin{array}{l}7.19-7.28 \\
(11 / 11)\end{array}$ & $\begin{array}{l}7.22-7.34 \\
(20 / 21)\end{array}$ & $\begin{array}{l}7.21-7.33 \\
(18 / 18)\end{array}$ & $\begin{array}{l}7.22-7.3 \\
(6 / 6)\end{array}$ \\
\hline $\mathrm{PaCO}_{2} \ddagger$ & $\begin{array}{l}51 \\
42.6-61.1 \\
(63 / 70)\end{array}$ & $\begin{array}{l}55 \\
49-67 \\
(45 / 45)\end{array}$ & $\begin{array}{l}37.2 \\
30.5-40.7 \\
(18 / 18)\end{array}$ & $\begin{array}{l}45 \\
37.6-59.5 \\
(23 / 27)\end{array}$ & $\begin{array}{l}59.5 \\
53.7-65 \\
(12 / 12)\end{array}$ & $\begin{array}{l}37 \\
34.1-41 \\
(11 / 11)\end{array}$ & $\begin{array}{l}75.6 \\
70.8-86.3 \\
(39 / 39)\end{array}$ & $\begin{array}{l}77 \\
65-78.5 \\
(11 / 11)\end{array}$ & $\begin{array}{l}71 \\
60.7-93 \\
(20 / 21)\end{array}$ & $\begin{array}{l}72.5 \\
64.7-97 \\
(18 / 18)\end{array}$ & $\begin{array}{l}70.9 \\
68.4-72.7 \\
(6 / 6)\end{array}$ \\
\hline $\mathrm{PaO}_{2} \ddagger$ & $\begin{array}{l}56 \\
46-71.2 \\
(62 / 70)\end{array}$ & $\begin{array}{l}56 \\
44.7-65.8 \\
(44 / 45)\end{array}$ & $\begin{array}{l}62.5 \\
47.2-74.4 \\
(18 / 18)\end{array}$ & $\begin{array}{l}54 \\
47.6-63 \\
(23 / 27)\end{array}$ & $\begin{array}{l}49.5 \\
47-54.2 \\
(12 / 12)\end{array}$ & $\begin{array}{l}60 \\
52.1-67 \\
(11 / 11)\end{array}$ & $\begin{array}{l}61 \\
47-73 \\
(37 / 39)\end{array}$ & $\begin{array}{l}65 \\
43.7-77.5 \\
(11 / 11)\end{array}$ & $\begin{array}{l}52.1 \\
46-72.5 \\
(20 / 21)\end{array}$ & $\begin{array}{l}50.3 \\
39.5-69 \\
(18 / 18)\end{array}$ & $\begin{array}{l}64.5 \\
55.5-72.9 \\
(6 / 6)\end{array}$ \\
\hline $\mathrm{PaO}_{2} / \mathrm{FiO}_{2} \ddagger$ & $\begin{array}{l}185 \\
134-242.2 \\
(32 / 70)\end{array}$ & $\begin{array}{l}165.5 \\
129-231.5 \\
(24 / 45)\end{array}$ & $\begin{array}{l}223 \\
204.2-244 \\
(9 / 18)\end{array}$ & $\begin{array}{l}142 \\
91.5-196.7 \\
(12 / 27)\end{array}$ & $\begin{array}{l}175.5 \\
111.7-237.7 \\
(6 / 12)\end{array}$ & $\begin{array}{l}105.5 \\
86-173 \\
(6 / 11)\end{array}$ & $\begin{array}{l}184 \\
154.5-213.5 \\
(15 / 39)\end{array}$ & $\begin{array}{l}191 \\
116.5-257.2 \\
(6 / 11)\end{array}$ & $\begin{array}{l}161 \\
144-240 \\
(9 / 21)\end{array}$ & $\begin{array}{l}197.5 \\
146.2-243.7 \\
(8 / 18)\end{array}$ & $\begin{array}{l}252 \\
218.5-295 \\
(3 / 6)\end{array}$ \\
\hline
\end{tabular}

APACHE, Acute Physiology and Chronic Health Evaluation; CPE, cardiogenic pulmonary oedema; COPD, chronic obstructive pulmonary disease; F/M, female/male; ob-hypoven, obesityhypoventilation decompensation.

*Trials with available arterial blood gas data: CPE 63/70; pneumonia 23/27; pneumonia + COPD 20/21.

†Mean \pm standard deviation.

$\ddagger$ Median, interquartile range (available data/number trials).

overall success rate of $64 \%{ }^{26}$ The difference in success rate with respect to RCTs could be because of three principal reasons. The first one is related to the setting where our patients were treated: initially in an emergency ward and subsequently in an understaffed intermediate care unit. Monitoring levels and intensity of nursing care were lower than usually offered in ICUs, where most RCTs on NIV were performed. Second, the selection of our patients for NIV was not as strict as in the RCTs where patients not candidate for intubation were excluded-for example, in the study of Brochard et $a l^{2}$ 69\% of patients admitted with ARF for exacerbation of COPD were excluded from the NIV trial. In our series, of 63 patients who failed the NIV trial for inefficacy, 50 were not considered eligible for intubation and 48 died. These patients received non-invasive ventilation as "ceiling treatment" for their ARF. The third reason for different outcomes involves the absence of double blinding in the RCTs on NIV. Because of the nature of the intervention (applying a mask to the patient), double blinding of treatment assignment was not possible for NIV studies, probably overestimating the treatment effect. ${ }^{27}$

As for outcomes of single categories of disease, the higher success rate obtained in the subgroup of patients with CPE $(78.6 \%)$ in comparison with others subgroups is most

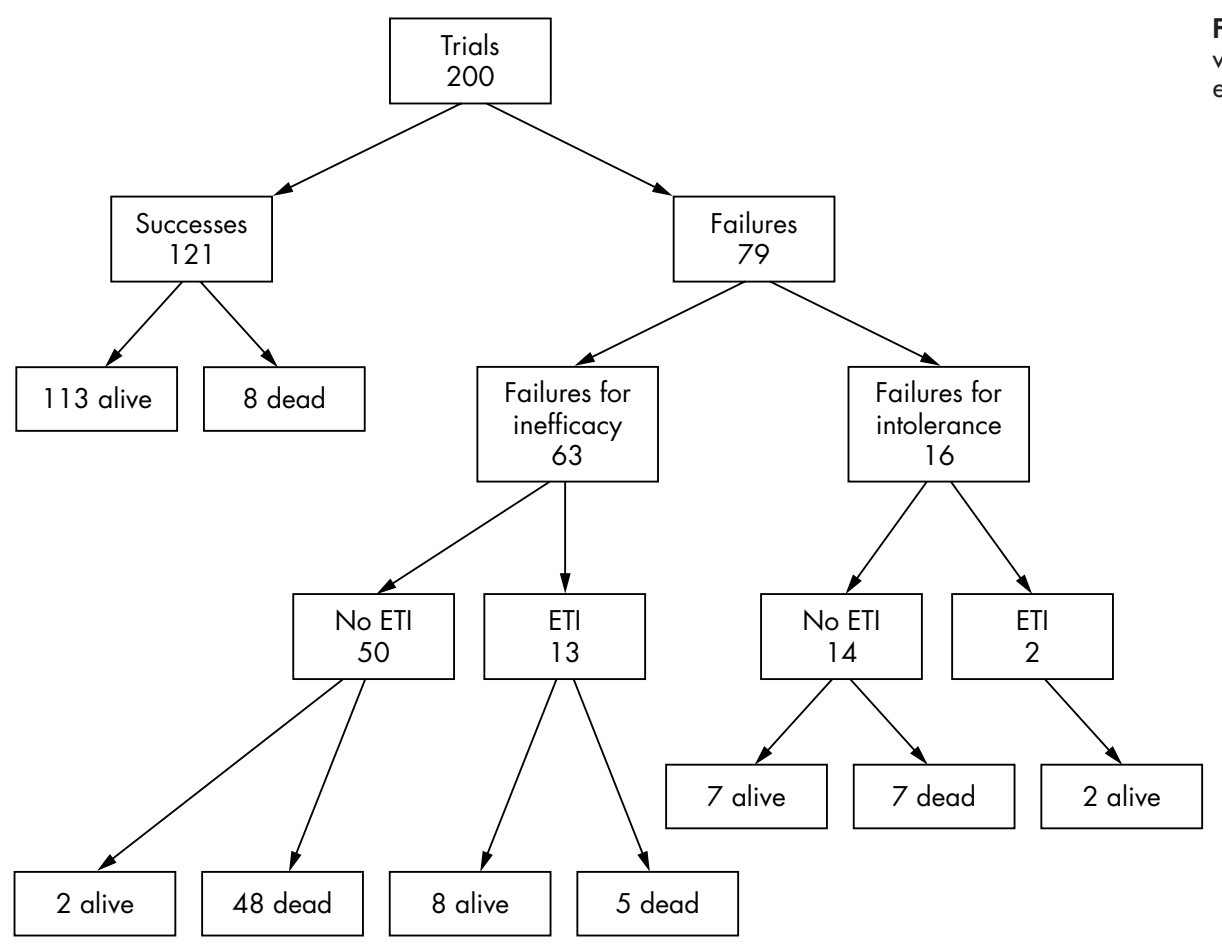

Figure 1 Outcomes of non-invasive ventilation (NIV) trials. ETI endotracheal intubation 


\begin{tabular}{|c|c|}
\hline Successful trials, number and \% & $121(60.5 \%)$ \\
\hline Failures, number and $\%$ & 79 (39.5\%) \\
\hline $\begin{array}{l}\text { Intolerance } \\
\text { Inefficacy: }\end{array}$ & $16(8 \%)$ \\
\hline Early* & $52(26 \%)$ \\
\hline Late $†$ & $11(5.5 \%)$ \\
\hline Intubation, number and \% & $13(6.5 \%)$ \\
\hline Tracheostomy, number and \% & $2(1 \%)$ \\
\hline $\begin{array}{l}\text { HDU mortality, number (and \%) } \\
\text { of patients }\end{array}$ & $52(27.4 \%)$ \\
\hline $\begin{array}{l}\text { Global mortality, number (and \%) } \\
\text { of patients }\end{array}$ & $68(34.5 \%)$ \\
\hline $\begin{array}{l}\text { Mortality predicted by APACHE II } \\
\text { HDU length of stay, } \\
\text { median days (IQR) }\end{array}$ & $\begin{array}{l}32 \% \\
6(3-10)\end{array}$ \\
\hline $\begin{array}{l}\text { Hospital length of stay, } \\
\text { median days (IQR) }\end{array}$ & $15(8-26)$ \\
\hline \multicolumn{2}{|c|}{$\begin{array}{l}\text { APACHE, Acute Physiology and Chronic Health Evaluation; HDU, high } \\
\text { dependency unit; IQR, interquartile range. } \\
\text { 'Early: failure within } 48 \text { hours of NIV; tLate: failure after } 48 \text { hours of } \\
\text { NIV. }\end{array}$} \\
\hline
\end{tabular}

probably because of the ready reversibility of heart failure with medical treatment, which can work quite fast and so reduce the time during which the patient needs to be ventilated. The median NIV duration in these patients was 7 hours versus 24 hours (IQ 6-72 h) in the global population. The low success rate obtained in patients with community acquired pneumonia (CAP) confirms the results of previous studies indicating the poor efficacy of NIV in this type of patients. ${ }^{28}$ In a randomised trial in patients with severe CAP, Confalonieri $e t a l^{17}$ found, at a post hoc analysis, that the CAP subgroup with COPD randomised to NIV had a significant reduction in intubation rate, duration of intermediate respiratory ICU stay, and mortality at two months from study entry. The group of CAP patients with COPD in our study had a mortality rate of $50 \%$ at hospital discharge, slightly lower than that of CAP patients without COPD (57\%), but a lower success rate of NIV (28.6\% v 37\%, respectively). Both groups of CAP patients had a mortality rate higher than that predicted by APACHE II-that is, 38.6\% in CAP patients with COPD and $30.1 \%$ in CAP patients without COPD. We believe the high death rate of CAP patients in our series to be related to their high comorbidity and high number of patients with do-not-intubate codes (44.4\% in CAP patients and $42.8 \%$ in CAP patients with COPD).

Another finding in our study of "real clinical practice" is the presence of a high number of patients who are not considered candidate for invasive mechanical ventilation and for whom NIV is delivered as "ceiling" treatment. Actually, in our series, the rate of ETI $(6.5 \%)$ was relatively low, mainly because of the high number of patients who refused or were otherwise judged not candidate for invasive mechanical ventilation. Many of these patients received NIV for palliative reasons. Consequently, mortality rate at hospital discharge was $34.5 \%$ in our series $(6.6 \%$ in NIV responders and $75.9 \%$ in NIV non-responders), which is much higher than in RCTs, where patients for whom ETI is not an option are not eligible to the study. In our series, those patients constituted a large part of global population $(32 \%)$. With the limits of a retrospective study, these last results should induce a serious rethinking of the value and opportunity of NIV in patients who are not candidate for ETI.

\section{ACKNOWLEDGEMENTS}

We thank Dr Enrica Migliore, statistician of the Department of Epidemiology, for reviewing the data and providing detailed statistical analysis.

\section{Authors' affiliations}

A Camillo, M Franca, U Rosario, G Valerio, Dipartimento di Emergenza e Accettazione, Ospedale San Giovanni Battista, Torino, Italy

Funding: none

\section{Competing interests: none declared}

The Corresponding Author has the right to grant on behalf of all authors and does grant on behalf of all authors, an exclusive licence (or non exclusive for government employees) on a worldwide basis to the BMJ Publishing Group Ltd and its Licensees to permit this article (if accepted) to be published in EMJ editions and any other BMJPGL products to exploit all subsidiary rights, as set out in our licence.

\section{REFERENCES}

1 Bott J, Carroll MP, Conway JH, et al. Randomised controlled trial of nasal ventilation in acute ventilatory failure due to chronic obstructive airway disease. Lancet 1993;341:1555-7.

2 Brochard L, Mancebo J, Wysocki M, et al. Non-invasive ventilation for acute exacerbations of chronic obstructive pulmonary disease. N Engl J Med 1995;333:817-22.

3 Kramer N, Meyer TJ, Meharg J, et al. Randomized, prospective trial of noninvasive positive pressure ventilation in acute respiratory failure. Am J Respir Crit Care Med 1995;151:1799-806.

4 Martin TJ, Hovis JD, Costantino JP, et al. A randomized prospective evaluation of noninvasive ventilation for acute respiratory failure. Am J Respir Crit Care Med 2000; 161:807-13.

5 Plant PK, Owen JL, Elliot MW. Early use of noninvasive ventilation for acute exacerbation of chronic obstructive pulmonary disease on general respiratory wards: a multicentre randomised controlled trial. Lancet 2000;355:1931-5.

Table 4 Outcomes for categories of disease

\begin{tabular}{|c|c|c|c|c|c|c|c|c|c|c|c|}
\hline & \multicolumn{3}{|l|}{ CPE } & \multicolumn{3}{|c|}{ Pneumonia } & \multirow[b]{2}{*}{ COPD } & \multirow[b]{2}{*}{ CPE + COPD } & \multirow[b]{2}{*}{$\begin{array}{l}\text { Pneumonia } \\
+ \text { COPD }\end{array}$} & \multirow{2}{*}{$\begin{array}{l}\text { Hypercapnic } \\
\text { pneumonia } \\
\text { + COPD }\end{array}$} & \multirow[b]{2}{*}{$\begin{array}{l}\text { Ob- } \\
\text { hypoven }\end{array}$} \\
\hline & Total & Hypercapnic & $\begin{array}{l}\text { Non- } \\
\text { hypercapnic }\end{array}$ & Total & Hypercapnic & $\begin{array}{l}\text { Non- } \\
\text { hypercapnic }\end{array}$ & & & & & \\
\hline $\begin{array}{l}\text { Number } \\
\text { trials }\end{array}$ & $70^{*}$ & 45 & 18 & $27^{*}$ & 12 & 11 & 39 & 11 & $21^{*}$ & 18 & 6 \\
\hline $\begin{array}{l}\text { Number } \\
\text { patients }\end{array}$ & 69 & 44 & 18 & 26 & 12 & 11 & 37 & 11 & 20 & 17 & 6 \\
\hline Successest & $\begin{array}{l}55 / 70 \\
(78.6 \%)\end{array}$ & $38 / 45$ (84.4\%) & ) 13/18 (72.2\%) & $\begin{array}{l}10 / 27 \\
(37 \%)\end{array}$ & $5 / 12(41.6 \%)$ & $4 / 11(36.4 \%)$ & $\begin{array}{l}25 / 39 \\
(64.1 \%)\end{array}$ & $6 / 11(54.5 \%)$ & $6 / 21(28.6 \%)$ & ) $5 / 18$ (27.8\%) & $\begin{array}{l}6 / 6 \\
(100 \%)\end{array}$ \\
\hline $\begin{array}{l}\text { Actual } \\
\text { mortality } \dagger\end{array}$ & $\begin{array}{l}16 / 69 \\
(23.1 \%)\end{array}$ & $8 / 44(18.2 \%)$ & $6 / 18$ (33.3\%) & $\begin{array}{l}15 / 26 \\
157.7 \%\end{array}$ & $8 / 12(66.7 \%)$ & $5 / 11(45.4 \%)$ & $\begin{array}{l}11 / 37 \\
(29.7 \%)\end{array}$ & $2 / 11(18.2 \%)$ & $10 / 20(50 \%)$ & $9 / 17(52.9 \%)$ & $0 / 6$ \\
\hline $\begin{array}{l}\text { APACHE II } \\
\text { predicted } \\
\text { mortality }\end{array}$ & $21.9 \%$ & & & $30.1 \%$ & & & $24.8 \%$ & NA & $38.9 \%$ & & NA \\
\hline
\end{tabular}

APACHE, Acute Physiology and Chronic Health Evaluation; CPE, cardiogenic pulmonary oedema; COPD, chronic obstructive pulmonary disease; ob-hypoven, obesity-hypoventilation decompensation; NA, not applicable.

${ }^{*}$ number (\%); †trials with available arterial blood gas data: CPE 63/70, pneumonia 23/27, pneumonia + COPD 20/21 
6 Antonelli M Conti G, Rocco M et al. A comparison of non-invasive positive pressure ventilation and conventional mechanical ventilation in patients with acute respiratory failure. N Engl J Med 1998;339:429-35.

7 Declaux C, L'Here Alberti C, et al. Treatment of acute hypoxemic nonhypercapnic respiratory insufficiency with continuous positive airway pressure delivery by a face mask: a randomised controlled trial. JAMA 2000;284:2352-60

8 Peter JV, Moran JL, Phillips-Hughes J, et al. Noninvasive ventilation in acute respiratory failure - A meta-analysis update. Crit Care Med 2002; 30:555-62.

9 Pang D, Keenan SP, Cook DJ, et al. The effect of positive pressure airway support on mortality and the need for intubation in cardiogenic pulmonary edema: a systematic review. Chest 1998;114:1185-92.

10 Lightowler JV, Wedzicha JA, Elliott MW, et al. Non-invasive positive pressure ventilation to treat respiratory failure resulting from exacerbations of chronic obstructive pulmonary disease: Cochrane systematic review and metaanalysis. BMJ 2003;326:185-7.

11 Brochard L. Non-invasive ventilation for acute exacerbations of COPD: a new standard of care. Thorax 2000:55:817-18.

12 Elliott MW. Non-invasive ventilation in acute exacerbations of chronic obstructive pulmonary disease: a new gold standard? Intensive Care Med 2002;28:1691-4.

13 Bersten AD, Holt AW, Vedig AE, et al. Treatment of severe cardiogenic pulmonary edema with continuous positive airway pressure delivered by face mask. N Eng J Med 1991;325:1825-30.

14 Lin M, Yang YF, Chiang HT, et al. Reappraisal of continuous positive airway pressure therapy in acute cardiogenic pulmonary edema. Short-term results and long-term follow-up. Chest 1995;107:1379-86.

15 Nava S, Carbone G, DiBattista N, et al. Noninvasive ventilation in cardiogenic pulmonary edema: a multicenter randomized trial. Am J Respir Crit Care Med 2003; 168:1432-7.

16 Antonelli M, Conti, Bufi M, et al. Noninvasive ventilation for treatment of acute respiratory failure in patients undergoing solid organ transplantation: a randomised trial. JAMA 2000;283:235-41.
17 Confalonieri M, Potena A, Carbone G, et al. Acute respiratory failure in patients with severe community-acquired pneumonia. A prospective randomized evaluation of noninvasive ventilation. Am J Respir Crit Care Med 1999: 160:1585-91.

18 Ferrer $M$, Esquinas $A$, Leon $M$, et al. Noninvasive ventilation in severe hypoxemic respiratory failure. A randomised clinical trial. Am J Respir Crit Care Med 2003; 168:1438-44.

19 American Thoracic Society. International consensus conferences in intensive care medicine: noninvasive positive pressure ventilation in acute respiratory failure. Am J Respir Crit Care Med 2001;163:283-91.

20 British Thoracic Society Guidelines. Non-invasive ventilation in acute respiratory failure. Thorax 2002;57:192-211

21 Soo Hoo GW, Santiago S, Williams AJ. Nasal mechanical ventilation for hypercapnic respiratory failure in chronic obstructive pulmonary disease: determinants of success and failure. Crit Care Med 1994:22:1253-61.

22 Ambrosino N, Foglio K, Rubini F, et al. Non-invasive mechanical ventilation in acute respiratory failure due to chronic obstructive airways disease: correlates for success. Thorax 1995;50:755-7.

23 Alsous F, Amoateng-Adjepong Y, Manthous CA. Noninvasive ventilation: experience at a community teaching hospital. Intensive Care Medicine 1999;25:458-63.

24 Sinuff T, Cook DJ, Randall J, et al. Noninvasive positive-pressure ventilation: a utilization review of use in a teaching hospital. CMAJ 2000;163(8):969-73.

25 Sinuff T, Cook DJ, Randall J, et al. Evaluation of a practice guideline for noninvasive positive-pressure ventilation for acute respiratory failure. Chest 2003;123:2062-73.

26 Girault C, Briel A, Hellot M-F, et al. Noninvasive mechanical ventilation in clinical practice: a 2-year experience in a medical intensive care unit. Crit Care Med 2003:31:552-9.

27 Magder S. The limitations of evidence from randomised trials. CMAJ 2000; 163(8):986-7.

28 Antonelli M, Conti G, Moro ML, et al. Predictors of failure of noninvasive positive pressure ventilation in patients with acute respiratory failure: a multicenter study. Intensive Care Med 2001;27(11):1718-28.

Table 5 Predictive factors (adjusted for age and sex) of non-invasive ventilation (NIV) success and death

\begin{tabular}{|c|c|c|c|c|c|c|}
\hline & \multicolumn{3}{|c|}{ Overall } & \multicolumn{3}{|c|}{ Hypercapnic group } \\
\hline & OR & $\mathrm{Cl} 95 \%$ & $\mathbf{p}$ & OR & Cl $95 \%$ & $\mathbf{p}$ \\
\hline $\begin{array}{l}\text { Age, years } \\
\text { Sex (male }=1) \\
\text { APACHE II } \\
\mathrm{pH}^{*} \\
\mathrm{PaCO}_{2}(\mathrm{~mm} \mathrm{Hg}) \\
\text { Decreased level of } \\
\text { consciousness }\end{array}$ & $\begin{array}{l}0.99 \\
1.88 \\
0.89 \\
1.00 \\
0.99 \\
0.75\end{array}$ & $\begin{array}{l}0.97-1.01 \\
1.04-3.31 \\
0.83-0.94 \\
0.97-1.03 \\
0.98-1.01 \\
0.48-1.20\end{array}$ & $\begin{array}{l}0.499 \\
0.035 \\
0.001 \\
0.897 \\
0.237 \\
0.231\end{array}$ & $\begin{array}{l}0.99 \\
1.70 \\
0.86 \\
1.01 \\
0.97 \\
0.70\end{array}$ & $\begin{array}{l}0.96-1.02 \\
0.85-3.37 \\
0.80-0.93 \\
0.97-1.05 \\
0.96-0.99 \\
0.41-1.20\end{array}$ & $\begin{array}{l}0.132 \\
0.633 \\
0.001 \\
0.499 \\
0.017 \\
0.193\end{array}$ \\
\hline \multirow{2}{*}{$\begin{array}{l}\text { Decreased level of } \\
\text { consciousness }\end{array}$} & \multicolumn{3}{|c|}{ Overall } & \multicolumn{3}{|c|}{ Hypercapnic group } \\
\hline & OR & $\mathrm{Cl} 95 \%$ & $\mathbf{p}$ & OR & Cl $95 \%$ & p \\
\hline Age, years & 1.03 & $1.00-1.05$ & 0.039 & 1.03 & $0.99-1.06$ & 0.102 \\
\hline Sex $($ male $=1)$ & 0.58 & $0.32-1.06$ & 0.075 & 0.49 & $0.24-1.02$ & 0.057 \\
\hline APACHE ॥ & 1.09 & $1.03-1.16$ & 0.003 & 1.12 & $1.04-1.20$ & 0.003 \\
\hline $\mathrm{pH}^{*}$ & 1.01 & $0.98-1.04$ & 0.640 & 0.98 & $0.94-1.02$ & 0.315 \\
\hline \multirow{4}{*}{$\begin{array}{l}\mathrm{PaCO}_{2}(\mathrm{~mm} \mathrm{Hg}) \\
\text { Decreased level of } \\
\text { consciousness } \\
+\mathrm{PaCO}_{2} 6 \mathrm{~h} \\
+\mathrm{pH} 6 \mathrm{~h}\end{array}$} & 1.00 & $0.98-1.01$ & 0.612 & 1.01 & $0.99-1.03$ & 0.410 \\
\hline & 1.55 & $0.97-2.51$ & 0.067 & 1.65 & $0.93-2.91$ & 0.085 \\
\hline & 0.44 & $0.17-1.14$ & 0.091 & 0.33 & $0.97-1.13$ & 0.078 \\
\hline & 0.16 & $0.05-0.50$ & 0.002 & 0.14 & $0.03-0.62$ & 0.009 \\
\hline
\end{tabular}

*pH values were multiplied for 100 . The $\mathrm{OR}$ obtained is for $\mathrm{pH}$ increments of 0.01 .

tImprovement of $\mathrm{PaCO}_{2}$ and $\mathrm{pH}$ within $6 \mathrm{~h}$ after NIV initiation. 